Vol. 5, No. 1, 2021

\title{
ANALYSIS ON IMPOSITION OF SAFEGUARD MEASURE AND ADMINISTRATIVE SANCTION AGAINST TAX EVASION OF TEXTILES TAX AND TEXTILES PRODUCT IN INDONESIA
}

\author{
Muhammad Itqonul Humam ${ }^{1}$, Akhmad Firdiansyah ${ }^{2}$ \\ Politeknik Keuangan Negara STAN \\ E-mail: 1401190274_itqonul@pknstan.ac.id
}

\section{INFORMASI ARTIKEL}

Tanggal masuk

[07-03-2021]

Revisi

[29- 03-2021]

Tanggal terima

[21-05-2021]

\begin{abstract}
:
Import of textile product which keeps getting higher has caused serious injury to the domestic textile industry, as an effort to protect domestic industry government has imposed additional import duty in form of safeguard duty for import of textiles product. The introduction of safeguard duty is expected to allow domestic industry to adjust itself for competing with import products, but the establishment of safeguard duty for the textile products is thought to be the trigger for tax evasion on the import of textile products, against this violation government impose the administrative sanction. The purpose of this research is to analyze the effect of safeguard duty imposition and administration sanctions on tax evasion. The object of this research is all import activity on textiles product which has been imposed safeguard duty and committing administrative violation since the establishment of safeguard duty for textile product beginning on November 2019 till October 2020. The regression technique used is ordinary least square regression to regress cross-section data. Research conclusion finds that safeguard duty introduction significantly affecting tax evasion while administrative sanction didn't have a significant effect on reducing tax evasion.
\end{abstract}

Keywords: textile product, safeguard duty, administration sanction, tax evasion. 


\section{INTRODUCTION}

Trade liberalization has proven to be able to stimulate industrialization that spurs economic growth, this can be seen from the history of rapid economic growth such as in China, Japan, Hong Kong, Taiwan, Singapore, and South Korea which cannot be separated from the existence of trade cooperation with other countries Rachmawati \& Indrasari (2017). Although trade liberalization also has a negative impact, namely the free trade agreement (FTA) which results in the elimination of import duties so that tax revenues are reduced and there is a tendency to increase in import activities, an increase in the volume of imports will be a threat to domestic industries. SantosPaulino (2002) proves that the elimination of trade barriers in the form of import duties has a positive correlation with an increase in import volume. Furthermore, Nambiar et al. (1999) stated that if these imported goods compete directly with domestically produced goods, a surge in imports could endanger domestic industries.

The high demographic figure of Indonesia and the existence of the AseanChina Free Trade Agreement (ACFTA) trade agreement certainly make the
Indonesian market very attractive to China. China became the largest supplier of fabrics and fabric products in Indonesia in 2018 with a market share of $67.86 \%$ and followed by Korea with $11.07 \%$. Throughout the 2016-2019 period there has been a very sharp spike in imports of fabric products. In the table presented from 2016-2018 the increase in imports of fabric products was $22.54 \%$ in the 2016-2017 period and jumped sharply to $41.76 \%$ in the $2017-2018$ period, for the January-June 2018-2019 period or during the first 6 months of the year 2018-2019 the increase was also seen from 182,541 tons to 211,112 tons.

\begin{tabular}{|c|c|c|c|c|c|c|c|c|c|}
\hline \multirow{3}{*}{ Deskripsi } & \multicolumn{5}{|c|}{ Tahun } & \multicolumn{3}{|c|}{ Pertumbuhan (\%) } & \multirow{3}{*}{$\begin{array}{c}\text { Tren }(\%) \\
16-18\end{array}$} \\
\hline & \multirow{2}{*}{2016} & \multirow{2}{*}{2017} & \multirow{2}{*}{2018} & \multicolumn{2}{|c|}{ Januari.Juni } & \multirow{2}{*}{$16-17$} & \multirow{2}{*}{17.18} & \multirow{2}{*}{$\begin{array}{c}\text { Jan-Jun } \\
18-19\end{array}$} & \\
\hline & & & & 2018 & 2019 & & & & \\
\hline $\begin{array}{l}\text { Jumlah Impor } \\
\text { (Ton) }\end{array}$ & 238.219 & 291.915 & 413.813 & 182.541 & 211.112 & 22,54 & 41,76 & 15,65 & 31,80 \\
\hline
\end{tabular}

Source: (BPS dalam KPPI, 2019)

On average, the increase in imports reached $31.80 \%$ per year. Imports of fabric products are thought to be very strong causing losses to the domestic industry, especially since the fabric and fabric products industry is the industrial sector that absorbs the most labor when compared to other manufacturing industry sectors (BPS, 2017) so that the closure of the domestic textile industry will have an 
impact. serious to the reduction of fieldwork in Indonesia.

In order to overcome this, the World Trade Organization (WTO) has provided provisions regulating the protection of domestic industries, namely through safeguard measures stipulated in the General Agreement on Tariff and Trade (GATT) Article XIX. This provision provides an opportunity for export destination countries to take precautionary measures against a surge in imports to their country if the import is proven to cause serious losses to domestic industry (WTO, 1968). The provisions of the WTO are adopted into Indonesian legislation through Law Number 7 of 1994 concerning Ratification of the Agreement Establishing the WTO and are further regulated in Government Regulation No. 34 of 2011 concerning Antidumping Measures, Compensation Measures, and Trade Safeguard Measures. With the adoption of the WTO provisions, if the interested parties feel that they have been affected by serious losses due to the surge in imports, they can submit a request for an investigation to the Indonesian Trade Safeguard Commission which is under the Ministry of Trade.

The KPPI investigation then proved that it was true that there had been serious losses to the domestic industry as a result of the surge in imports (KPPI, 2020). For this, KPPI recommends the imposition of Safeguard Measure Import Duty (BMTP) on imported fabric products for 2 years and followed up by the Ministry of Finance by issuing PMK No. 162/010/2020 concerning Imposing Safeguard Measures Import Duty on Imported Fabrics.

The imposition of BMTP is an exception to the general import duty (most favored nation) so that if it is included in the trade agreement (FTA) scheme, BMTP is an additional preferential import duty, this additional import duty generally depends on the quantity and type of fabric imported at the lowest rate. is IDR 1,318 / meter and the highest is IDR 11,426/ meter.

The enactment of the imposition of BMTP on fabric products certainly makes the price of imported fabric products soar, the hope is that the domestic industry will have the opportunity to adjust structurally so that when the imposition of BMTP ends the domestic industry can compete with imported goods.

Violations of customs provisions in the import of fabric products result in the imposition of sanctions, both administrative sanctions and criminal 
sanctions depending on the violations committed. The government has regulated administrative sanctions for these violations in the Customs Law and is further regulated in Government Regulation No. 39 of 2019 concerning the Imposition of Administrative Sanctions in the form of Fines in the Customs Sector.

Tax evasion is intentional illegal behavior that leads to violations of tax law to avoid paying taxes according to Réthi (2012) in Khlif \& Achek (2015). Sandmo (2005) also argues that tax evasion is a violation of tax law where taxpayers refrain from reporting income that is taxable in principle. Thus tax evasion represents a deliberate fraud on the tax information that is by the way not to report financial assets, the taxable income and profit as well as trade mispricing (Khlif \& Achek, 2015)

This study aims to analyze empirically whether this fight tax evasion (tax evasion) by not reporting tax obligations are actually on imports of fabric products have a correlation with the implementation of Safeguard Measures Import Duty on fabric products and whether the administrative sanction customs imposed correlated with tax evasion.

\section{LITERATURE REVIEW}

\subsection{International Trade Theory}

In the theory of international trade formulated by Eli Hekscher and Bertil Ohlin and later better known as the Hekscher-Ohlin theorem, it is explained that a country will produce goods that use abundant production factors and use them intensively (Morrow, 2010).

China is a country that has an abundance in production factors in the form of labor and raw materials that are available in abundance and cheap which can make China have a comparative advantage in the global competition for world fabrics and make China the largest producer and exporter of textile products in the world (Yuan \& Xu, 2007), so it is necessary to carry out an analysis of Indonesia's interests as a consideration in policymaking to create a win-win solution between the two.

\subsection{Tax Evasion}

Tax evasion is one form of tax noncompliance other than tax avoidance. According to Kay (1980) in Yitzhaki (1974), the thing that distinguishes the most between the two is that tax evasion tries to manipulate transactions illegally, while tax avoidance recognizes transactions legally but is regulated in such a way as to cause tax treatment to be different from 
what the tax provisions should

be intended for. . Tax non-compliance itself is defined as the failure of taxpayers to fulfill their tax obligations regardless of whether this was done intentionally or unintentionally James $\quad \& \quad$ Alley (2009). According to Hasseldine \& $\mathrm{Li}$ (1999) the tax evasion action carried out by the importer can be explained by using the economic deterrence model approach. The economic deterrence model departs from the deterrence theory and the expected utility theory which predicts that the tax evasion behavior by taxpayers will tend to be greater if the economic benefits from the tax evasion are greater than the costs that must be borne if the tax the evasion was caught and subject to punishment.

Allingham \& Sandmo (1972) found that tax evasion is closely correlated with the probability of detection of the tax evasion, the tax rate itself, and the number of fines that will be imposed if the tax evasion efforts are known by the tax authorities. Fisman \& Wei (2004) in their research that analyzes the relationship between tax rates and tax evasion in imports between China and Hong Kong, concludes that every $1 \%$ increase in tax rate is associated with a $3 \%$ increase in tax evasion, besides that the evasion gap has a negative correlation with the tax rate on goods. closely related goods which indicate that tax evasion occurs through the misclassification of imported goods from goods with high tax categories to low tax categories as well as through reporting the value of imports below the actual value. Park \& Hyun (2003) concluded that the level of audit and level of sanctions are important factors in preventing tax evasion, however, based on experiments conducted, the imposition of sanctions is more effective in preventing tax evasion behavior.

Gemmell \& Hasseldine (2012) tried to conclude the tax evasion measurement method based on various literature in circulation and describe it into two groups of approaches, namely the micro approach and the macro approach.

The micro approach is a direct approach in measuring tax evasion. This approach tries to measure lost taxes or unreported income. One example of this approach is the audit method used by the United States Internal Revenue Service (IRS) in the Taxpayer Compliance Measurement Program in 19631988. Apart from the audit method, the survey method is also a micro approach in 
measuring the determinants of tax evasion, such as research conducted by Riahi-Belkaoui (2004), Richardson (2006), and Tsakumis et al. (2007). The macro approach according to Gemmell \& Hasseldine (2012) uses estimates from the hidden economy, the method used includes the discrepancy method which compares the reported income data with independent measurements of trusted income including hidden income, then the single indicator method which assumes a direct relationship between hidden sizes, income with other variables such as labor participation, transactions, currency, and electricity use, the last method is the multiple indicator multiple cause (MIMIC) method.

\subsection{Safeguard Duty}

Safeguard duty or also known as safeguards measure, is a provision determined by the World Trade Organization through GATT Article XIX as a tool that can be used by the state if it is industrial domestic sector proved to be seriously affected as a result of the surge in imports, provisions this was adopted by the government through Government Regulation No. 34 of 2011 on Antidumping Measures, Countervailing Measures, and Safeguard Measures. According to the Government Regulation, security measures are defined as actions taken by the government to recover serious losses or prevent the threat of serious losses suffered by the domestic industry as a result of a surge in the number of imported good either absolutely or relatively to similar goods or goods that directly compete with imported goods.

In general safeguard duty is Additional Import Duty outside of General Import Duty, with specific tariff which varies from Rp1.318/meter - Rp11.426/meter of fabric imported, depending on classification.

In Indonesia, safeguard duty and import tax is levied by The Directorat General of Customs and Excise under The Ministry of Finance. Importer has to declare and pay the import duty and import tax by themselves upon arrival, import duty is the amount of general import duty and additional import duty (if any), the value of the goods is determined using CIF incoterm which consists of cost or goods value, freight, and insurance multiplied by exchange rate during the date of import, resulting in the customs value. Customs value plus import duty is then called import value which becomes the basis of determining import tax. Import tax consists of import income tax 
and value-added tax.

\subsection{Previous Research}

Research on tax evasion has been carried out with various independent variables and various levels such as the level of transactions between countries. Allingham \& Sandmo (1972) concluded that probability of detection, tariff rates, and penalties are closely related to tax evasion behavior. Richardson (2006) in his research, which took a sample of 45 countries, concluded that the most dominant factor affecting tax evasion is non-economic factors, namely complexity, other than that other factors that have a significant effect are the source of income, education level, tax fairness, and tax morale. Fisman \& Wei (2004) examined various import tax rates in China and found that tax evasion is closely related to the tax rates imposed by China, confirming the loss of higher taxes on products with high import taxes. Miskam et al. (2013) who examined the relationship between tax evasion and motor vehicle excise rates in motor vehicle smuggling cases in Malaysia found that the tariff and penalty factors were positively correlated while the firm size factor had a negative correlation with tax evasion. Park \& Hyun
(2003) use an experimental approach in determining the determinants of tax evasion and empirically conclude that taxpayers have the same level of compliance regardless of income level, both the audit level and the sanction level are very important tools to prevent tax evasion but the imposition of sanctions is found. more effectively, the three taxpayers tend to become free riders in financing the government, the fourth tax education is a very effective tool so that taxpayers are more obedient.

From Indonesia itself, research on the topic of tax evasion mostly uses a micro approach with survey methods with varying results, such as Ardyaksa \& Kiswanto (2014) which concluded that the accuracy of the allocation of expenditures, taxation technology, and information has a negative effect on tax evasion. Suminarsasi \& Supriyadi (2012) found that the taxation system has a positive association with taxpayer ethical perceptions, discrimination has a negative association with taxpayer ethical perceptions and a positive association between tax justice and taxpayer ethics cannot be proven. Paramita \& Budiasih (2016) with the same questionnaire method found that the taxation system and tax justice had a negative effect on 
Vol. 5, No. 1, 2021

$\begin{array}{lr}\text { taxpayers' } & \text { perceptions } \\ \text { evasion behavior while tax } & \text { taxation } \\ \text { technology had no negative effect. }\end{array}$ Concerning tax evasion in the customs sector in Indonesia Yubiwini \& Patunru (2018) estimated the tax evasion based on trade data between Indonesia and Singapore at the 6-digit Harmonized System (HS) classification level and found evidence that export figures from Singapore were reported to be lower at The Directorate General of Customs and Excise and embezzlement increases along with the increase in import duties.

\section{RESEARCH METHODE}

\subsection{Data}

In this study, the data used is secondary data obtained from the customs and excise service application system (CEISA / Customs and Excise Information System Automation). The data in question is in the form of Tax in the Context of Import (PDRI) and BMTP data reported by the importer in the Import Declaration (PIB), PDRI and BMTP data which should be based on the Tariff and Customs Value Notification Letter (SPTNP), HS Code of imported goods, tariffs. BMTP imposed, administrative sanctions imposed and company asset data. Data collection procedures that will be carried out in this study are the method of documentation and literature study.

\subsection{Research Variables and Operational Variables}

This study, using three variables, namely the dependent variable, the independent variable, and the control variable. The dependent variable of this study is stated as the tax evasion while the independent variable consists of BMTP and Administrative Sanctions, as the control variable company size is used.

The dependent variable to be examined in this study is tax evasion (TEV). The concept of tax evasion used in this study refers to the micro approach methodology in measuring tax evasion as described in the journal Gemmell \& Hasseldine (2012) which explains that

"The micro approach in measuring tax evasion is measured based on taxpayer data or a survey to identify the extent of tax non-compliance or unreported income".

Tax evasion is measured as the difference between the tax that should be paid based on the inspection by the officer and the tax reported divided by the customs value, or it can be stated by the following formula: 


\section{$T E V i=\frac{\left(P P h_{p}+P P N_{p}\right)-\left(P P h_{i}+P P N_{i}\right)}{N P}$ \\ TEV : Tax Evasion \\ $P P h_{p}$ : Income Tax according to customs officer examination \\ $P P N_{p}$ : VAT according to customs officer examination \\ $P P h_{i} \quad$ : Income Tax according to importer import declaration \\ $P P N_{i} \quad$ : VAT according to impoerter import declaration \\ NP : Customs Value}

The element of import duty is not included in the calculation with the consideration of differences in the treatment of import duties if the exporting country is a country that is included in a trade agreement, the import duty will be zero, but if there is no trade agreement between the two countries, the applicable import duty is general import duty (MFN).

The independent variable in this research is safeguard duty and administrative sanction

1) Safeguard Duty

The variable BMTP (BMTP) states the number of additional costs that must be incurred by importers to import goods that have received trade security measures based on the Regulation of the Minister of Finance. BMTP uses a ratio scale and is measured by dividing the total BMTP based on the results of an inspection by customs officials with the total customs value.
2) Administrative Sanction

Variable administrative sanctions (DENDA) are sanctions imposed for violations stipulated in the Customs Law, for example failing to convey the number and types of goods according to the provisions. The administrative sanctions variable is stated as the natural logarithm of the number of administrative sanctions (Miskam et al., 2013)

\section{3) Control Variable}

This study uses the control variable (SIZE) in the form of company size. Miskam et al (2013) use the number of employees as a proxy for company size, but according to Shalit \& Sankar (1977) total assets are more representative to be used as a proxy for company size, therefore in this study, the authors use the natural logarithm of total assets as a proxy for company size.

\subsection{Research Hypothesis}

Based on the description above the authors formulate a hypothesis

1. H1: Imposition of Safeguard Measures Import Duty has a positive effect on tax evasion

2. H2: The imposition of administrative sanctions has a negative effect on tax evasion

\subsection{Statistic Descriptive Analysis}

Descriptive statistics are statistics that provide data such as frequency, average, 
and standard deviation which provide descriptive information about a data set (Sekaran \& Bougie, 2016). The descriptive statistical analysis aims to provide an overview for researchers about the state or status of phenomena related to research problems based on the data collected (Budiwanto, 2017). The analysis was carried out by using the classical assumption test, normality test, multicollinearity test, and heteroscedastic test.

\section{RESULT AND DISCUSSION}

\section{Classical Assumption Testing}

The results of the normality test show the following results:

\begin{tabular}{|l|l|l|l|l|l|}
\hline $\begin{array}{l}\text { Varia } \\
\text { ble }\end{array}$ & $\begin{array}{l}\text { Ob } \\
\text { s }\end{array}$ & $\begin{array}{l}\text { Pr(Skewn } \\
\text { ess) }\end{array}$ & $\begin{array}{l}\text { Pr(Kurto } \\
\text { sis) }\end{array}$ & $\begin{array}{l}\text { Adj } \\
\text { chi2( } \\
\text { 2) }\end{array}$ & $\begin{array}{l}\text { Prob>c } \\
\text { hi2 }\end{array}$ \\
\hline TEV & $\begin{array}{l}34 \\
8\end{array}$ & 0.0000 & 0.0000 &. & 0.0000 \\
\hline BMTP & $\begin{array}{l}34 \\
8\end{array}$ & 0.0000 & 0.0000 &. & 0.0000 \\
\hline $\begin{array}{l}\text { lnDen } \\
\text { da }\end{array}$ & $\begin{array}{l}34 \\
8\end{array}$ & 0.0000 & 0.0000 &. & 0.0000 \\
\hline InSize & $\begin{array}{l}34 \\
8\end{array}$ & 0.4884 & 0.0211 & 5.79 & 0.0552 \\
\hline
\end{tabular}

From the table above, it can be seen that the test results show that all variables show an abnormal residual distribution. This can be seen from the Pr (Skewness) and Pr (Kurtosis) numbers which all show numbers below 0.05. Maulana \& Muchtar (2018) argue that normality is often not fulfilled because data is distorted and data conditions are naturally not normally distributed.

Regarding the relationship between residual normality and the number of observations, there is a theorem called the Central Limit Theorema (CLT) which states that research conducted with a large number of observations does not need to question normality, this is because the normality test only plays an important role when the number of observations is small (Kwak \& Kim, 2017). Gujarati \& Porter (2009) say that the number of observations in a study can be said to be large if the number of observations (n) is more than 100. The number of observations in this study is 348 observations, so according to CLT, the residual distribution in this study can be considered normal even though the results of the skewness- test kurtosis show the test results are not normally distributed. The multicollinearity test results are as follows

\begin{tabular}{|l|l|l|}
\hline Variable & VIF & 1/VIF \\
\hline intercept & 342.28 & 0.002922 \\
\hline lnDenda & 224.51 & 0.004454 \\
\hline InSize & 142.67 & 0.007009 \\
\hline BMTP & 1.08 & 0.925237 \\
\hline Mean VIF & 177.64 & \\
\hline
\end{tabular}


Based on the above results and compared with the standard parameters for the VIF test, it can be seen that the lnSIZE and lnDENDA variables experience multicollinearity problems, while the BMTP variable is free from multicollinearity problems. Therefore, a centering technique was carried out on the $\operatorname{lnDENDA}$ and $\operatorname{lnSIZE}$ variables to solve this problem. After centering the VIF test was carried out again on all variables and the results are shown in the table below:

\begin{tabular}{|l|l|l|}
\hline Variable & VIF & $\mathbf{1}$ /VIF \\
\hline BMTP & 1.08 & 0.925237 \\
\hline intercept & 1.08 & 0.926612 \\
\hline InDENDAC & 1.01 & 0.994200 \\
\hline lnSIZEC & 1.00 & 0.995361 \\
\hline Mean VIF & 1.04 & \\
\hline
\end{tabular}

After the centering technique was carried out, the STATA application embedded an additional $\mathrm{C}$ behind the centering variable so that the lnDENDA variable became $\operatorname{lnDENDAC}$ and $\operatorname{lnSIZE}$ became $\operatorname{lnSIZEC}$. There was a significant change in the VIF and 1 / VIF values of the lnDENDAC and lnSIZEC variables when compared before the centering technique was carried out. After doing the centering technique, the $\operatorname{lnDENDAC}$ and $\operatorname{lnSIZEC}$ variables got the respective values of 1,00 and 1.01 and 1 / VIF respectively 0.99442 and 0.9953661 so that both of them were free from multicollinearity problems.

The results of the heteroscedasticity test with the Breusch-Pagan test showed the following results:

\begin{tabular}{|l|}
\hline $\begin{array}{l}\text { Breusch-Pagan / Cook-Weisberg test for } \\
\text { heteroskedasticity }\end{array}$ \\
\hline Ho: Constant variance \\
\hline Variables: fitted values of TEV \\
\hline chi2 $(1)=6.27$ \\
\hline Prob $>$ chi2 $=0.0123$ \\
\hline
\end{tabular}

The test results show the value Prob> chi2 at 0,0123 . Because the value of Prob> chi2 is less than 0.05, the conclusion drawn is that the regression model used has a residual variance that is not constant or heteroscedastic so it has a heteroscedasticity problem.

According to Maulana and Muchtar (2018) several ways can be taken to overcome the heteroscedasticity problem such as adding sample data, transforming data into logs, ln, rank, and so on, using robust options when performing regression, using other estimation models such as Generalized Least. Square (GLS) and use a regression model with $\mathrm{ARCH}$ order 1 . In this study the authors chose to use the robust option in performing regression, thus the heteroscedasticity 
problem in the regression model of this study can be considered complete.

\section{Hypothesis Testing}

After the variables used in this study have successfully passed the classical assumption test, then hypothesis testing can be done using multiple linear regression with the OLS approach. The regression results show the following results:

\begin{tabular}{|c|c|c|c|c|c|}
\hline \multirow{2}{*}{\multicolumn{2}{|c|}{$\begin{array}{l}\text { Number of obs } \\
\text { F } \\
\text { Prob } \gg F\end{array}$}} & & \multirow{2}{*}{$\begin{array}{l}348 \\
: 4719.29 \\
0.0000\end{array}$} & \multirow{2}{*}{$\begin{array}{l}\mathrm{R}^{2} \\
\text { Root MSE }\end{array}$} & \multirow{2}{*}{$\begin{array}{l}: 0.9475 \\
: 0.04316\end{array}$} \\
\hline & & & & & \\
\hline TEV & Coeff & $\begin{array}{l}\text { Robust } \\
\text { Std. Err. }\end{array}$ & t & $P>t$ & $95 \%$ Conf Interval \\
\hline BMTP & 1010218 & .0008712 & 2115.96 & 0.000 & $\begin{array}{lll}.0993083 & .0273\end{array}$ \\
\hline InDendaC & - 0015009. & .0018388 & $8-0.82$ & 0.415 & 0021158. \\
\hline InSizeC & .0018688 & .0007603 & 2.46 & 0.014 & 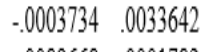 \\
\hline OOls & & & -2.05 & 0.041 & .0089668 \\
\hline
\end{tabular}

The coefficient of determination $\left(\mathrm{R}^{2)}\right.$ shows the number 0.9475 , this means that $94.75 \%$ of the change in the dependent variable that tax evasion can be explained by the independent variables namely Safeguard Duty (BMTP), administrative sanctions (Denda) and the size of the company (Size) and $5.25 \%$ is explained by other variables which are not included in the object of research in this study.

Figures Prob> F which features a simultaneous significance level of 0.0000 which means the figures show the overall variables used in this study the BMTP, administrative sanctions, and measures

companies simultaneously able to deliver a significant influence on tax evasion.

The partial significance test or also known as the $t$ statistical test aims to test the effect of each independent variable on the dependent. The results of the partial significance test are shown in the probability column $\mathrm{t}(\mathrm{P}>|\mathrm{t}|)$. The explanation of the results of the $t$ statistical test is as follows:

1) The t probability value of the security measure import duty (BMTP) variable is 0,0000 . This value is smaller than $\alpha$ 0,05 so it can be concluded that the variable of security measures import duty has a significant effect on tax evasion.

2) The $t$ probability value of the administrative sanctions variable (lnDendaC) shows the number 0.415 which is greater than $\alpha 0,05$, thus it can be concluded that the administrative sanctions variable does not have a significant effect on tax evasion.

3) The t probability value of the firm size variable $(\ln S i z e C)$ is 0.014 . This value is still below the threshold level of confidence $\alpha 0,05$ so it means that company size has a significant effect on tax evasion.

\section{Discussion}


After OLS regression has been carried out through classical assumption testing and goodness of fit test, the regression equation in this study can be written with the coefficients obtained based on the regression results as follows:

$$
\begin{aligned}
T E V_{I}=-0.0045725+0.1010218 B M T P_{i} \\
\\
-0.0015009 \ln D E N D A C_{i} \\
+0.0018688 \ln S I Z E C_{i}+0.02234
\end{aligned}
$$

This equation shows the relationship between the independent and dependent variables which can be translated as follows:

1) The variable of security measure import duty (BMTP) has a regression coefficient of 0,1010218 . This means that if other variables are constant, a $1 \%$ increase in import duty security measures will have a positive effect on the increase in tax evasion by 0.1010218 or about $10.1 \%$.

2) The administrative sanctions variable (lnDENDAC) produces a regression coefficient of -0.0015009 , which means that if other variables are constant, a $1 \%$ increase in administrative sanctions will reduce the tax evasion by 0.001509 or about $0.15 \%$.

3) The firm size variable (lnSIZEC) produces a regression coefficient of 0.0018688 . This means that if other variables are constant, a $1 \%$ increase in company size will increase the tax evasion by 0.0018688 or about $0.18 \%$.

Testing of the imposition of import duty on safeguard measures on tax evasion is proven to have a significant and positive effect. This proves that the higher the import duty for security measures that must be paid by the importer, the higher the tax evasion will be carried out. From the resulting coefficient, it can be seen that a $1 \%$ increase in BMTP will have the effect of a $10 \%$ increase in tax evasion.

This finding strengthens various previous studies such as research by Fisman and Wei (2004) which found a 3\% correlation in the increase in tax evasion from every $1 \%$ increase in import duties on trade between China and Hong Kong, besides that Yousefi et al. (2020) also concluded similar findings but slightly below that is $2.5 \%$ tax evasion for every $1 \%$ increase in import taxes between Iran and its 21 trading partner countries, as well as Mengistu et al. (2019), found the same thing in Ethiopia, even Miskam et al., (2013) found The correlation reached $21.3 \%$ increase in tax evasion in the case of car smuggling in Malaysia. The findings above indicate that the tax evasion phenomenon in the customs sector, especially smuggling, is a 
phenomenon that is commonly found in various countries, especially developing countries (Buehn $\&$ Farzanegan, 2012).

Tax evasion carried out by importers can be viewed from the economic deterrence theory as proposed by Hasseldine and Li (1999) which departs from the earliest theories regarding tax evasion by Allingham and Sandmo (1972). The earliest theories regarding tax evasion consider taxpayers to be riskneutral decision-makers and try to maximize their utility. In this framework, the factors that determine the cost of compliance include, among others, the tax rate, the probability of detection, the level of income, and the penalty structure, all of which direct how taxpayers behave to obey or not.

As explained above, the tax evasion carried out by importers has a very close relationship with the imposition of BMTP on fabric products. This BMTP was imposed after the surge in imports of fabric products from China caused serious losses to the domestic industry. The surge in fabric products from China is due to China being a country with competitive advantages in producing fabric products Yuan \& Xu (2007) so that fabric products made in China are cheap and of high quality. With the imposition of BMTP, imported fabric products will be more expensive and it is hoped that the domestic fabric product producer industry will have the opportunity to catch up in terms of production quality and price with imported products.

According to Sheikh (1973) whatever causes price discrimination between the national and foreign markets of a good, this will create an incentive for smuggling, so that when the government sets high tariffs for importing a good, the price of the good will increase which results in smugglers. will be motivated to carry out smuggling for more profit. The existence of this smuggling cannot be separated from the interest of the domestic market to enjoy the quality and cheap fabric products.

Still, according to Sheikh (1989), the demand for smuggled products also depends on various factors such as moral standards and risk profiles and what is equally important is the existence of antismuggling laws besides the difference in prices between goods produced domestically and imported goods produced by the community. feel that the benefits obtained from importing illegally (tax-evasion / mis invoicing / misclassification) are worth the risk so that 
consumers will seek cheaper prices illegally.

The results of the partial significance test show that the imposition of customs administration sanctions in the form of fines apparently did not contribute significantly to reduce tax evasion. This is contrary to much of the literature that proves that the imposition of sanctions or penalties is correlated with a decrease in tax evasion (Miskam et al., 2013; Park \& Hyun, 2003)

After digging deeper into the data obtained by the author, we found the fact that most violations are only given administrative sanctions in the form of a fine with a nominal value of Rp5,000,000. This is regulated in Indonesia Customs Law No. 10/1995 Article 114 paragraph 1 and 2 as follow

All violations which are subject to administrative sanctions in the form of fines are calculated based on a percentage of the import duty, if the tariff or final tariff is the zero percent for goods related to the violation, then against this violation, the offender is subject to administrative sanctions in the form of a fine of IDR 5,000,000.00.

After ASEAN and China Free Trade Agreement (ACFTA) is ratified, practically most of the customs tariffs between China and ASEAN become 0\%, accordingly any related violations for this kind of import subject to a fine with a flat nominal value of Rp. 5,000,000.00. Apart from fines the importer must also pay for the shortfall in taxes and duties enter the security measures owed based on the inspection of the customs official.

The low nominal sanction is suspected to be the main reason why the imposition of administrative sanctions has not been able to reduce tax evasion, this relatively small nominal value makes the importer assume that the risk borne becomes insignificant when compared to the benefits that will be obtained from the savings in having to pay taxes and safeguard duty. Especially with the channeling system in process of importing goods into three channels, namely the red, yellow and green channels, then the importer has more incentive to hide the true obligation due to the hope that their goods get the green lane so that they are not subject to inspection.

This is in accordance with the opinion of Becker (1968) in Raskolnikov (2006) which sees that the taxpayer's decision to carry out tax evasion is a problem choice under uncertainty or can technically be called gambling. Taxpayer who knows that the tax evasion action he does has the 
potential to subject to sanctions equal to $\mathrm{X}$ will compare it with that gain expected if the action is successful. This model concludes if expected value generated from this gambling is positive then the taxpayer will do tax evasion, and if it is negative then taxpayers will obey its tax obligations.

In the data obtained by the author, it is also found that many companies breaking more than once during the observation period, few companies even violate more than five times. This proves that many companies didn't take sanctions imposed. seriously According to Waerzeggers et al., (2019) imposition of fines can become ineffective in preventing tax evasion if the sanction in the form of a fine is seen as part of the tax expense by the taxpayer, particularly if the monetary amount is from sanctions are not sufficient to be an effective deterrent. This is also the case with administrative sanctions in this study, where the amount of Rp. 5,000,000 has been proven in this study there is no significant effect in preventing tax evasion because the amount is not sufficient to prevent tax evasion by importers so that importers can consider the sanction only as an additional cost to import and tend to continue to commit offenses.

\section{CLOSING}

\section{Conclusion}

1) The imposition of customs entry security measures positively and significantly correlated with the increase in tax evasion. The greater the import duty for security measures imposed, the greater the tax evasion carried out by the importer.

2) The imposition of administrative sanctions has no significant effect on reducing tax evasion. This can occur because the amount of administrative sanctions imposed is insignificant to cause a deterrence effect on importers so that importers can consider administrative sanctions imposed as part of the cost of importing.

Researchers who are interested in continuing this research can further develop hypotheses by including other variables such as customs value, then the importer's risk profile based on tracking and it can also be further investigated whether the symptoms of tax evasion also occur in goods subject to general import duty rates (most favored nation). In addition, it is also interesting to have a further review regarding the implementation of the imposition of import duties on this security measure from the side of service users, both importers and Customs Brokers (PPJK). 


\section{REFERENCES}

Allingham, M. G., \& Sandmo, A. (1972). Income Tax Evasion: A Theoretical Analysis. Journal of Public Economics, 1(7), 323-338. https://doi.org/10.4324/9781315185 194

Ardyaksa, T. K., \& Kiswanto. (2014). Pengaruh Keadilan, Tarif Pajak, Ketepatan Pengalokasian, Kecurangan, Teknologi Dan Informasi Perpajakan Terhadap Tax Evasion. Accounting Analysis Journal, 3(4), 475-484. https://doi.org/10.15294/aaj.v3i4.420 9

Becker, G. S. (1968). Crime and Punishment: An Economic Approach. Journal of Political Economy, 76(2), 169-217. https://doi.org/10.1002/9780470752 135.ch25

Budiwanto, S. (2017). Metode Statistika Untuk Mengolah Data Keolahragaan. Universitas Negeri Malang.

Buehn, A., \& Farzanegan, M. R. (2012). Smuggling around the world: Evidence from a structural equation model. Applied Economics, 44(23), 3047-3064.

https://doi.org/10.1080/00036846.20 11.570715

Fisman, R., \& Wei, S. J. (2004). Tax rates and tax evasion: Evidence from "missing imports" in China. Journal of Political Economy, 112(2), 471496. https://doi.org/10.1086/381476

Gemmell, N., \& Hasseldine, J. (2012). The tax gap: A methodological review. In Advances in Taxation (Vol. 20).
https://doi.org/10.1108/S10587497(2012)0000020011

Gujarati, D. N., \& Porter, D. C. (2009). Basic Econometrics 5th Edition (5th ed.). Mc Graw-Hill/Irwin.

Hasseldine, J., \& Li, Z. (1999). More tax evasion research required in new millennium. Crime, Law and Social Change, 31(2), 91-104. https://doi.org/10.1023/A:10083247 26125

Indonesia, K. P. P. (2019). Laporan Preliminary Determination Dalam Rangka Rekomendasi Pengenaan Bea Masuk Tindakan Pengamanan Sementara (BMTPS) Terhadap Impor Kain.

James, S., \& Alley, C. (2009). Tax Compliance, Self-Assessment and Tax Administration. Journal of Finance and Management in Public Services, 2(4), 27-42.

Khlif, H., \& Achek, I. (2015). The determinants of tax evasion: a literature review. International Journal of Law and Management, 57(6), 486-497. https://doi.org/10.1108/IJLMA-032014-0027

Kwak, S. G., \& Kim, J. H. (2017). Central limit theorem: The cornerstone of modern statistics. Korean Journal of Anesthesiology, 70(2), 144-156. https://doi.org/10.4097/kjae.2017.70. 2.144

Maulana, T. I., \& Muchtar, P. P. S. A. (2018). Modul Metode Penelitian Akuntansi. Politeknik Keuangan Negara STAN.

Mengistu, A. T., Molla, K. G., \& Mascagni, G. (2019). Tax Evasion 
and Missing Imports: Evidence From Transaction-Level

Data. www.ictd.ac/publication

Miskam, M., Noor, R. M., Omar, N., \& Aziz, R. A. (2013). Determinants of Tax Evasion on Imported Vehicles. Procedia Economics and Finance, 7(ICEBR), 205-212. https://doi.org/10.1016/s22125671(13)00236-0

Morrow, P. M. (2010). RicardianHeckscher-Ohlin comparative advantage: Theory and evidence. Journal of International Economics, $82(2)$, 137-151. https://doi.org/10.1016/j.jinteco.201 0.08 .006

Nambiar, R. G., Mungekar, B. L., \& Tadas, G. A. (1999). Is import liberalisation hurting domestic industry and employment. Economic and Political Weekly, 34(7), 417424.

Park, C. G., \& Hyun, J. K. (2003). Examining the determinants of tax compliance by experimental data: A case of Korea. Journal of Policy Modeling, 25(8), 673-684. https://doi.org/10.1016/S01618938(03)00075-9

Rachmawati, F. I., \& Indrasari, D. P. R. (2017). Pengaruh Kebijakan Bea Masuk Tindakan Pengamanan (BMTP) Terhadap Price Cost Margin Industri Manufaktur. Jurnal Riset Ekonomi Dan Manajemen, 17(1), 147-160.

https://doi.org/https://doi.org/10.312 89/mercatoria.v10i1.616

Raskolnikov, A. (2006). Crime and Punishment in Taxation: Deceit, Deterrence and teh Self Adjisting
Penalty. Columbia Law Review, 106(3), 569-642.

Réthi, G. (2012). Relation between tax evasion and Hofstede's $4+2$ model. European Journal of Management, 12(3), 61-72.

Riahi-Belkaoui, A. (2004). Relationship between tax compliance internationally and selected determinants of tax morale. Journal of International Accounting, Auditing and Taxation, 13(2), 135-143. https://doi.org/10.1016/j.intaccaudta x.2004.09.001

Richardson, G. (2006). Determinants of tax evasion: A cross-country investigation. Journal of International Accounting, Auditing and Taxation, 15(2), 150-169. https://doi.org/10.1016/j.intaccaudta x.2006.08.005

Sandmo, A. (2005). The theory of tax evasion: A retrospective view. National Tax Journal, 58(4), 643663. https://doi.org/10.17310/ntj.2005.4.0 2

Santos-paulino, A. U. (2002). The Effects of Trade Liberalization on Imports in Selected Developing Countries. 30(6), 959-974.

Shalit, S. S., \& Sankar, U. (1977). The Measurement of Firm Size. The Review of Economics and Statistics, 59(3), 290. https://doi.org/10.2307/1925047

Sheikh, M. A. (1973). A Partial Equilibrium Model of Smuggling. Review of World Economics, 113(2), 268-283. 
Sheikh, M. A. (1989). A Theory of Risk, Smuggling and Welfare. 17(12), 1931-1944.

Suminarsasi, W., \& Supriyadi. (2012). Terhadap Persepsi Wajib Pajak Mengenai Etika Penggelapan Pajak (Tax Evasion). Seminar Nasional Akuntansi, 1(2), 0-29.

Tsakumis, G. T., Curatola, A. P., \& Porcano, T. M. (2007). The relation between national cultural dimensions and tax evasion. Journal of International Accounting, Auditing and Taxation, 16(2), 131-147. https://doi.org/10.1016/j.intaccaudta x.2007.06.004

Waerzeggers, C., Cory, H., \& Aw, I. (2019). Designing Interest and Tax Penalty Regimes. In Tax Law IMF Technical Notes. IMF Legal Department.

Yitzhaki, S. (1974). A Note on Allingham and Sandmo. Journal of Public Economics, 3(2), 201-202.

Yousefi, K., Vesal, M., \& Pilvar, H. (2020). Import tax evasion and avoidance: Evidence from Iran. Quarterly Review of Economics and Finance, 75, 31-39. https://doi.org/10.1016/j.qref.2019.0 5.010

Yuan, T., \& Xu, F. (2007). China's Textile Industry International Competitive Advantage and Policy Suggestion. Journal of the Washington Institute of China Studies, 2(1), 84-97.

Yubiwini, \& Patunru, A. (2018). Trade and tax evasion in Indonesia. World Customs Journal, 12(2), 107-120. 